\title{
Vibrissae amputation in mice and completion of a learned food-acquisition task
}

\author{
WILLIAM HOVSEPIAN and NEAL McCLANAHAN \\ Temple University, Philadelphia, Pennsylvania 19122
}

\begin{abstract}
The effect of vibrissae amputation on completion of a learned food-acquisition excursion was tested. The mice were trained to pass from a startbox through a tunnel to a food box. The vibrissae of one group were amputated, and the running time of that group was compared to the times of three control groups. The difference in running times between groups was not significant, indicating that vibrissae removal in mice does not significantly inhibit performance of a function vital to survival.
\end{abstract}

Most mammals and all primates but man have facial vibrissae (Van Horn, 1970). In nonprimate mammals, vibrissae functions are related to eye-blinking, orienting and biting reflexes, and olfaction. In mice, vibrissae length and spread appears to correlate with the species habitat (Kratochvil, 1968). Burrowing mice have short vibrissae with a small field of reach. In arboreal species, the vibrissae are longer, and the tactual field is greater. Vibrissae removal in rats significantly affected depth avoidance, with some of the subjects refusing to descend deep and shallow sides of a visual cliff apparatus (Schiffman et al., 1970). Werboff and Anderson (1967) found that vibrissae removal impaired the survival response of mice to a water submersion task.

How profoundly does vibrissae removal affect the behavior of mice? Would vibrissae amputation interfere with a common activity such as an excursion from one location through a small burrow to a known food source? This study was designed to assess the effect of vibrissae loss on mice confronted with a learned food-acquisition task similar to one which might be encountered in the natural environment.

\section{METHOD}

\section{Subjects}

Forty naive adult male Swiss mice were used as subjects.

\section{Apparatus}

The mice were trained and tested in two $33 \times 25.4 \times 25.4 \mathrm{~cm}$ containers connected by a tube $12.7 \mathrm{~cm}$ in length and $5.1 \mathrm{~cm}$ in diam inserted $3.8 \mathrm{~cm}$ above the floor in the center of the containers. The anaesthetic was given in glass jars containing ether-soaked cotton. The anaesthetic control was given in a glass jar containing untreated cotton. The vibrissae were amputated with surgical scissors or coated with Gulfwax paraffin. The mice were housed when not being tested in $45.7 \times 26.7 \times 12.7 \mathrm{~cm}$ steel and wire cages.

\section{Procedure}

The mice were housed together for 5 days before the

Calvin F. Nodine sponsors this paper and takes full editorial responsibility for its content. experiment. They were then food deprived for $24 \mathrm{~h}$ and trained to pass through the tunnel from the startbox to a food supply in the foodbox. The performance criterion was a startbox to foodbox latency of $20 \mathrm{sec}$ or less on three consecutive trials. After training, the mice were randomly assigned to one of four cages where they received ad-lib food and water for $24 \mathrm{~h}$.

Group I mice were then anaesthetized and their vibrissae were removed. Group II mice were anaesthetized and their vibrissae were brushed with melted wax until coated. Group III mice were anaesthetized and returned to their home cages without further treatment, anc the mice in Group IV were placed one at a time in the jar containing untreated cotton and returned to their home cages. After $24 \mathrm{~h}$ food deprivation, all the mice were placed one at a time in the startbox and running time to the foodbox was recorded.

\section{RESULTS}

All of the mice located the tunnel and passed through it to feed at the food site. The mean running times were $22.7 \mathrm{sec}$ for Group I, $13.6 \mathrm{sec}$ for Group II, $15.4 \mathrm{sec}$ for Group III, and $9.8 \mathrm{sec}$ for Group IV. These scores were analyzed with a one-way analysis of variance and were not significantly different at the .05 level $(\mathrm{F}=2.25)$.

\section{DISCUSSION}

Neither amputation nor wax coating of the vibrissae significantly affected task completion. However, it will be noted that the mean running time of the vibrissae-removed mice was longer $(22.7 \mathrm{sec})$ than those of the other groups. This difference was due almost entirely to one animal which took $78 \mathrm{sec}$ from startbox to foodbox. This one score was deleted, and a new mean running time was computed for Group I. The new mean $(16.5 \mathrm{sec})$, along with the mean running times of the other three groups, were analyzed again with a one-way analysis of variance and were not significantly different at the .05 level. It was evident that vibrissae removal does not significantly hamper execution of a simple survival task.

Placing vibrissae-amputated mice in a novel food-acquisition situation would continue the investigation of the effect of vibrissae loss. Shiffman et al。 (1970) reported impediment of visual cliff performance in vibrissae-removed rats. It is suspected that vibrissae amputation would significantly affect the exploratory behavior of mice in a novel environment such as they were exposed to in the preceding experiment. 


\section{REFERENCES}

Kratochvil, J. Das vibrissenfeld der europaeischen arten der gattung apodemus keup, 1929. Zoologické Listy, 1968, 17, 193-209.

Schiffman, H. R., Lore, R., Passafiume, J., \& Neeb, R. Role of vibrissae for depth perception in the rat (Rattus norvegicus). Animal Behavior, 1970, 18, 290-292.
Van Horn, R. N. Vibrissae structure in the rhesus monkey. Folia Primatologia, 1970, 13, 241-285.

Werboff, J., \& Anderson, A. Vibrissae and genetic background: Their role in a water submersion task with mice. Perceptual and Motor Skills, 1967, 24, 1143-1153.

(Received for publication May 1, 1975.) 